\title{
Impacts of Humic Acid, Indole Butyric Acid (IBA) and Arbuscular Mycorrhizal Fungi (Glomus mosseae) as Growth Promoters on Yield and Phytochemical Characteristics of Hibiscus Sabdariffa (Roselle)
}

\author{
Ramy G. El-Kinany ${ }^{1}$, Yossry E. Salama ${ }^{2}$, Mahmoud A. Rozan ${ }^{3}$, Hala M. Bayomy ${ }^{4}$ and Atef M.K. Nassar ${ }^{5}$
}

\begin{abstract}
Field experiments were carried out during the two successive summer seasons of 2015/2016 and 2016/2017. The experiments were accomplished in an open field located at Bader region, El-Beheira Governorate, Egypt to evaluate the effects of humic acid, indole butyric acid (IBA), and arbuscular mycorrhizal fungi (AMF) (Glomus mosseae) individually on vegetative growth, yield, and phytochemical characteristics of Hibiscus Sabdariffa (Roselle jamica). Experimental field plots were designed as randomized complete block design (RCBD). The obtained results of the two seasons, generally, showed that all treatments (HA, IBA, and AMF) individually enhanced the vegetative growth, yield of calyx, and phytochemical parameters of Roselle plants. The HA treatment was the most effective in enhancing most of the studied parameters and might be recommended for enhancing the vegetative growth, yield of calyx, and calyx phytochemical components of Roselle plants under the environmental conditions of Bader region, El-Beheira Governorate and other similar regions.
\end{abstract}

Keywords: Hibiscus Sabdariffa, Karkade, Humic acid, Indole butyric acid, Mycorrhizal.

\section{INTRODUCTION}

Roselle (Hibiscus sabdariffa L.) is an annual shrub and belongs to the family Malvaceae. It is cultivated in tropical and subtropical regions for its popular stem fibers, edible calyxes, leaves, and seeds (Mahadevan and Kamboj, 2009). It is a popular plant in Middle Eastern Countries and known with many names such as Roselle, Sorrel, Mesta, and Karkade (Abu-Tarboush and Ahmed, 1996). It is considered as one of the most popular medicinal plants for its antimicrobial and antioxidant activities due to its rich content of a wide range of phenolic compounds (Anokwuru et al., 2011). Also, it is used in folk therapy for abscesses, bilious conditions, cancer, cough, debility, dyspepsia, and fever (Lazim et al., 2014). The leaves are sedative and emollient. Calyces are used after being boiled in water in folk remedy for cancer (Duke, 1979) and considered a good source of protein (Mukhtar, 2007). Moreover, calyx used in the food and cosmetic industries as a natural coloring agent in beverage, jam, and jellies (Khalil and Abdel-Kader, 2011 and Sonar et al., 2013). The flowers of $H$. sabdariffa contain glycosides (hibiscin), anthocyanins, and gossyperin, which might exert diuretic and choleretic effects and decrease the viscosity of the blood that reduce the blood pressure (Hassan, 2009).

However, environmental stresses including heat, drought, and salinity limit the plant's productivity. Therefore, several additives were attempted to enhance the performance and productivity of plants. For example, humic acid, which is a mixture of compounds that exist in soils with high levels of organic matter and quinine chemicals and was generated by microbial decomposition of plant tissues (Thygesen et al., 2009). These compounds occur widely in soils, sediments, and water that contain carboxylic, phenolic, and methoxy chemicals (Xu et al., 2005). Humic acids directly affect the plants by affecting the root and shoot processes and increasing nutrients absorption (Lobartini et al., 1997). Many studies reported that humic acids could be used as growth promoters similar to gibberellic acids in improving plant growth and stress tolerance responses (Piccolo et al., 1992).

Additionally, plant growth hormones have been reported to affect root processes, such as auxins which commonly used to stimulate root initiation in plants (Looney and McIntosh, 1968). Indole 3-Butyric Acid (IBA) is one of the most important auxins used to promote the formation of roots by breaking root apical dominance induced by cytokinin in plants (Hartmann et al., 1990 and Cline, 2000). Recent investigations on IBA biosynthesis in plants showed that its concentrations might regulate plant responses to various stresses (Ludwig-Müller et al., 1995 and 2000). Also, numerous reports indicated that Arbuscular mycorrhizal fungi (AMF) set symbiosis relationship with most plant families (Smith and Read, 2008). The AMF improves plant growth and vegetative development, as well as increases the fruit yield (Dasgan et al., 2008 and Tüfenkçi et al., 2012). Arbuscular mycorrhizal fungi

DOI:: 10.21608/ASEJAIQJSAE.2020.73036

${ }^{1}$ Horticulture Department, Faculty of Agriculture, Damanhour University.

${ }^{2}$ Crop Science Department, Faculty of Agriculture, Damanhour University.

${ }^{3,4}$ Food Science and Technology Department, Faculty of Agriculture, Damanhour University.

${ }^{5}$ Plant Protection Department, Faculty of Agriculture, Damanhour University.

Damanhour, El-Beheira, P.O. Box 59, Egypt

Received Januury 06, 2020, Accepted February 13,2020 
control root settlement, which leads to better utilization of nutrients, particularly nitrogen, phosphorus, and microelements, from the rhizosphere (Dasgan et al., 2008 and Salvioli et al. 2012). Mwangi et al. (2011) reported a positive effect of AMF on plant growth and development is enhanced along with the decrease of rhizosphere abundance. Therefore, the objective of the current study was to investigate the effects of HA, IBA, and AMF on enhancing the vegetative growth, yield, and phytochemical characteristics of Hibiscus Sabdariffa (Roselle).

\section{MATERIALS AND METHODS}

\section{Field experimental design and growth promoter's treatment}

Field experiments were conducted during the two successive summer seasons of 2015/2016 and 2016/2017. The experiments were executed in an open field located at Bader region, El-Beheira Governorate, Egypt. Seeds of Roselle (local variety) were obtained from the Medicinal and Aromatic Plants Dept. Desert Research Center El-Mataria, Cairo, Egypt. Seeds were sown on the $1^{\text {st }}$ of April of each season in the field plots $(5 \times 5 \mathrm{~m})$, each plot contained 50 plants where the distance between rows was $100 \mathrm{~cm}$ and between plants within the row was $50 \mathrm{~cm}$ (Attia and Khater 2015). Soil samples were collected for physical and chemical analyses according to Black et al. (1965) and the results are shown in Table A. The analyses were carried out in the Department of Natural Resource and Engineering Soil, Faculty of Agriculture, Damanhour University.

Table A. Some physical and chemical analyses of the experimental soil in 2015/2016 and 2016/2017 growing seasons

\begin{tabular}{lcc}
\hline Parameter \& Unit & First season & Second season \\
\hline Sand (\%) & 47.3 & 46.8 \\
Silt $(\%)$ & 36.2 & 36.4 \\
Clay (\%) & 16.5 & 16.8 \\
& Sandy- & \\
Soil texture & loam & Sandy-loam \\
pH (in water) & 7.6 & 7.56 \\
EC (ds. ${ }^{-1}$ ) & 0.96 & 0.971 \\
Organic matter (\%) & 0.97 & 0.972 \\
Total N (\%) & 0.17 & 0.16 \\
Assimilable P (ppm) & 10.8 & 10.72 \\
Exchangeable K & 105 & 103 \\
(ppm) & & \\
\hline
\end{tabular}

Plants were treated with the following treatments: 1 control (tap water), 2- $100 \mathrm{ppm}$ solution of IBA as a spray treatment, 3- Humic acid was added as a ground application at a rate of $3 \mathrm{Kg} /$ Fadden. Indole butyric acid and humic acid were applied twice after 45 and 60 days of seed germination. 4- Mycorrhizal fungi (AMF) were applied as seed inoculation treatment (Glomus mosseae).

\section{The following data were recorded:}

\section{Vegetative growth characters and fruit yield}

Three plants from each experimental plot were randomly chosen and tagged for vegetative growth traits, notably: plant height $(\mathrm{cm})$, number of branches per plant, leaf area $\left(\mathrm{cm}^{2}\right)$ according to Zidan (1962). By the end of the experiment, stem diameter $(\mathrm{cm})$, shoot fresh and dry weights per plant $(\mathrm{g})$ were determined without the inflorescences and roots. At harvest stage (after 220 days of sowing), the number of fruits per plant, fruits fresh weight ( $\mathrm{g} / \mathrm{plant})$, and dry sepals yield per plant $(\mathrm{g})$ were determined.

\section{Chlorophyll and carotenoids analyses in leaves}

Leaf chlorophyll $\mathrm{a}$ and $\mathrm{b}$ and total carotenoid contents $(\mu \mathrm{g} / \mathrm{mL})$ were measured spectrophotometrically according to (Lichtenthaler and Buschmann, 2001).

\section{Phytochemical analyses of calyces}

A- Calyces were collected from each treatment then dried at $70^{\circ} \mathrm{C}$ to constant weights to determine: moisture contents, ash, and crude fiber which were determined by AOAC (2000) methods. Total lipids were extracted with chloroform: methanol (2:1) and quantified gravimetrically (Christie, 1983). The nitrogen content (N) of the sample was estimated by the method described by Kjeldahl (1983) and crude protein was calculated as $\mathrm{N} \times 6.25$. Total carbohydrate content was obtained by the difference between the weight of the sample and total weights of its moisture, ash, total lipid, protein, and fiber contents (Muler and Tobin, 1980).

B- Calyces belonging to each treatment were combined and dried at ambient temperature under shade in the open field. Then samples were ground into fine powders and were stored at $-20^{\circ} \mathrm{C}$ until been extracted for the phytochemical analyses. About $5 \mathrm{~g}$ of Roselle calyces were homogenized in $100 \mathrm{ml}$ of $0.1 \mathrm{~N} \mathrm{HCl}$ in ethanol (Du and Francis, 1973) to determine:

\section{Total anthocyanin contents}

Total anthocyanin contents of Roselle extract was determined calorimetrically according to Du and Francis (1973). Briefly, a $10 \mathrm{ml}$ volume of the filtered extract was diluted to $100 \mathrm{ml}$ with the extracting solvent. The colour intensity was measured at $535 \mathrm{~nm}$ for acidified ethanol using Spectrophotometer (model T80 x UVNIS Spectrometer PG Instruments Ltd). The total anthocyanin contents were calculated as mg cyanidin-3glucoside equivalent $/ \mathrm{mL}$ of extract. 


\section{Total flavonoid contents}

Flavonoid contents were determined according to Zilic et al. (2012). Briefly, $250 \mu \mathrm{l}$ of $5 \% \mathrm{NaNO}_{2}$ was mixed with $500 \mu \mathrm{l}$ of extract. After $6 \mathrm{~min}, 2.5 \mathrm{ml}$ of a $10 \% \mathrm{AlCl}_{3}$ solution was added. After $7 \mathrm{~min}, 1.25 \mathrm{ml}$ of $1 \mathrm{M} \mathrm{NaOH}$ was added, and the mixture was centrifuged at $5000 \mathrm{~g}$ for $10 \mathrm{~min}$. The absorbance of the supernatant was measured at $510 \mathrm{~nm}$ against the blank. The total flavonoid contents were expressed as $\mu \mathrm{g}$ of catechin equivalent $(\mathrm{CE}) / \mathrm{mL}$ of sample.

\section{Total phenolic contents}

Total phenolic contents were determined using the Folin-Ciocalteu reagent according to Singlton et al. (1999). Generally, $500 \mu \mathrm{l}$ from the extract was transferred into a test tube and oxidized with the addition of $250 \mu \mathrm{l}$ of Folin-Ciocalteu reagent. After 5 min, the mixture was neutralized with $1.25 \mathrm{ml}$ of $20 \%$ aqueous $\mathrm{Na}_{2} \mathrm{CO}_{3}$ solution. After $40 \mathrm{~min}$, the absorbance was measured at $725 \mathrm{~nm}$ against the solvent blank. The total phenolic contents were determined through a calibration curve of Gallic acid and expressed as $\mu \mathrm{g}$ of Gallic acid equivalent (GAE)/mL of sample.

\section{Determination of ascorbic acid content}

The calyx samples were alkaline-hydrolyzed according to Kim et al. (2006). About $1 \mathrm{~g}$ of each sample was placed in a quick fit conical flask with 20 $\mathrm{ml}$ of $\mathrm{NaOH}(2 \mathrm{M})$ and the flasks were flushed with $\mathrm{N}_{2}$ and the stopper was replaced. The samples were shacked at $180 \mathrm{rpm}$ for $4 \mathrm{~h}$ at room temperature. The $\mathrm{pH}$ was adjusted to 2 with $\mathrm{HCl}(6 \mathrm{M})$. The samples were centrifuged at $5000 \mathrm{rpm}$ for $10 \mathrm{~min}$ and the supernatant was collected. Phenolic compounds were extracted twice with $50 \mathrm{ml}$ ethyl acetate and ethyl ether 1:1. The organic phase was separated and evaporated at $45^{\circ} \mathrm{C}$ and the samples redissolved in $2 \mathrm{ml}$ methanol. Determination of ascorbic acid was determined using the indophenols method (AOAC, 2000).

\section{Analysis of phenolic compounds by HPLC}

The calyx samples were prepared for HPLC analysis as follows: $100 \mathrm{mg}$ of dry sample was extracted with 0.9 $\mathrm{ml}$ of $90 \% \mathrm{MeOH}$ (with $0.5 \mathrm{mM}$ meta-phosphoric acid and $0.02 \mathrm{mM}$ EDTA) in $1.5 \mathrm{ml}$ Eppendorf tubes. The tubes were vortexed for $60 \mathrm{~s}$, sonicated for $30 \mathrm{~min}$ in cold water $\left(4^{\circ} \mathrm{C}\right)$, and centrifuged for $15 \mathrm{~min}$ at $4^{\circ} \mathrm{C}$ at $5000 \mathrm{rpm}$. The supernatant was collected into a $1.5 \mathrm{ml}$ glass vial. The samples were re-extracted by adding 0.6 $\mathrm{ml}$ of extraction buffer as mentioned before and the supernatants were combined into the same $1.5 \mathrm{ml}$ glass vial. Supernatants in glass vials were vacuum-dried for $6-8 \mathrm{~h}$ in a speed-vac. Dried-samples were re-solubilized in $500 \mu \mathrm{l}$ of extraction buffer. Extracts were filtered into a $1 \mathrm{ml}$ HPLC glass vial using a $1 \mathrm{ml}$ syringe and a 0.2 $\mu \mathrm{m}$ nylon filter (Fisher Scientific, Ottawa, ON). About $50 \mu \mathrm{l}$ of each sample were injected twice into the HPLC.

The HPLC analysis was carried out using Agilent Technologies 1100 series liquid chromatography equipped with an autosampler and a diode-array detector. The analytical column was an Eclipse XDBC18 $(150 \times 4.6 \mu \mathrm{m} ; 5 \mu \mathrm{m})$ with a C18 guard column (Phenomenex, Torrance, CA). The mobile phase consisted of acetonitrile (solvent $\mathrm{A}$ ) and $2 \%$ acetic acid in water (v/v) (solvent B). The flow rate was kept at 0.8 $\mathrm{ml} / \mathrm{min}$ for a total run time of $70 \mathrm{~min}$ and the gradient program was as follows: $100 \% \mathrm{~B}$ to $85 \% \mathrm{~B}$ in $30 \mathrm{~min}$, $85 \% \mathrm{~B}$ to $50 \% \mathrm{~B}$ in $20 \mathrm{~min}, 50 \% \mathrm{~B}$ to $0 \% \mathrm{~B}$ in $5 \mathrm{~min}$ and $0 \% \mathrm{~B}$ to $100 \% \mathrm{~B}$ in $5 \mathrm{~min}$. The injection volume was $50 \mu \mathrm{l}$ and peaks were monitored simultaneously at 280 and $320 \mathrm{~nm}$ for the benzoic acid and cinnamic acid derivatives, respectively. Before injection, all samples were filtered through a $0.45 \mu \mathrm{m}$ Acrodisc syringe filter (Gelman Laboratory, MI). Peaks were identified by congruent retention times and UV spectra and compared with those of the standards.

\section{Determination of radical DPPH scavenging activity}

The free radical scavenging capacity of samples was determined using the 1,1-diphenyl-2-picrylhydrazyl (DPPH) according to Hwang and Do-Thi (2014). The final concentration was $50 \mu \mathrm{M}$ for DPPH and the final reaction volume was $3.0 \mathrm{ml}$. The absorbance at $517 \mathrm{~nm}$ was measured against a blank of pure methanol. Percent inhibition of the DPPH free radical was calculated by the following equation:

Inhibition $(\%)=100 \times\left(\mathrm{A}_{\text {control }}-\mathrm{A}_{\text {sample }}\right) / \mathrm{A}_{\text {control }}$

where:

Acontrol is the absorbance of the control reaction (containing all reagents except the test compound).

Asample is the absorbance of the test compound.

Also, the antioxidant activity was determined by means of a calibration curve prepared with Trolox and expressed as mg of Trolox equivalent (TE) per unit (volume or weight) of the sample.

\section{Determination of $\mathbf{p H}$ sample and total titratable acidity (TTA)}

The $\mathrm{pH}$ of Roselle calyx was measured using a $\mathrm{pH}$ meter (model Cyber Scan 500) standardized with buffer solutions of 4.0 and 7.0 according to the method of AOAC (2000). Total titratable acidity was expressed as $\%$ citric acid was determined by standard AOAC (2000) using $\mathrm{NaOH}(0.1 \mathrm{~N})$ and phenolphthalein as an indicator.

\section{Mineral content}

Iron $(\mathrm{Fe})$, magnesium $(\mathrm{Mg})$, and zinc $(\mathrm{Zn})$ were determined in aliquots of the solutions of the ash that were established according to the method of AOAC (2000) using an Atomic Absorption Spectrophotometer 
(Perkin-Elmer Model 2380 manufacture, USA). Calcium $(\mathrm{Ca})$, sodium $(\mathrm{Na})$, and potassium $(\mathrm{K})$ were determined using the Flame Photometer according to the method described by Pearson (1976).

\section{Experimental Design and statistical analysis}

The experiments were applied according to complete randomized blocks design (RCBD) with three replicates (Snedecor and Cochran, 1967). Data were statistically analyzed using SAS software program (2013). Comparisons among the means of different treatments were achieved using the revised least significant difference procedure at $\mathrm{P}=0.05$ level as illustrated by Al-Rawy and Khalf-Allah (1980).

\section{RESULTS AND DISCUSSION}

\section{Vegetative growth and yield}

Data for vegetative growth parameters of Roselle plants during the two growing seasons of 2015/2016 and 2016/2017 were given in Table (1). Regarding the effect of individual treatments of humic acid, indole butyric acid (IBA) and Arbuscular mycorrhizal fungi (AMF), data showed clearly that the application of these treatments significantly enhanced the vegetative growth parameters in both seasons. The obtained results showed that humic acid was the most effective treatment compared to the other treatments in increasing plant height $(203.07$ and $193.2 \mathrm{~cm})$, number of branches per plant (9.93 and 11.53), stem diameter (2.099 and 1.96 $\mathrm{cm})$, leaf area $\left(3.34\right.$ and $\left.3.35 \mathrm{~cm}^{2}\right)$, shoot fresh weight $(1068.97$ and $1083.70 \mathrm{~g})$ and shoot dry weight (247.19 and $250.91 \mathrm{~g}$ ) for the first and second season, respectively. The present results were in parallel with those reported by Khalil and Yousef (2014), AlMohammad et al. (2016) and Hewidy et al. (2018) on
Hibiscus sabdariffa L. and Said-Al Ahl et al. (2016) on dill.

The augmentation of vegetative growth parameters of Roselle plants might be attributed to the role of humic acid in improving soil structure, changing the physical properties of soil, promoting the chelation of many elements, and making nutrients available to plants. Subsequently, helping in correcting the plant chlorosis and enhancing of photosynthesis density and plant root respiration, which results in improved plant growth (Chen and Avid, 1990). Also, humic acid stimulates plant growth through absorption of major and minor elements, changes in membrane permeability, protein synthesis, enzyme activation, and the activation of biomass production (Ulukan, 2008). Moreover, humic acid plays an important role in improving nitrogen assimilation and at the same time facilitating the synthesis of chlorophyll, sugars, essential amino acids, vitamins, and oils (Khalil et al., 2012). It increases root growth by increasing cell elongation or root cell membrane permeability, which leads to increasing the water and nutrients uptake, so improving plant growth and development (Vaughan, 1974 and Rauthan and Schnitzer 1981).

The increase in fruit number per plant with humic acid treatment might be due to the superiority of this treatment in the number of branches and leaf area (Table 1), which led to increase photosynthesis (Jain, 2002), which in turn was reflected in increasing fruit number. Also, humic acid as an organic fertilizers improved the physical, chemical and microbiological characteristics of the soil (Atiyeh et al., 2000) and increased the holding capacity of soil (Eghbal et al., 2004), which lead to increase yield (Ahmadian et al., 2011 and Kalvanagh and Heris, 2013).

Table 1. Effect of HA, IBA and AMF treatments on vegetative growth characteristics and yield of Roselle plants during the two summer seasons of $2015 / 2016$ and 2016/2017

\begin{tabular}{|c|c|c|c|c|c|c|c|c|}
\hline \multirow{2}{*}{ Parameters } & \multicolumn{4}{|c|}{2016} & \multicolumn{4}{|c|}{2017} \\
\hline & Control & HA & IBA & AMF & Control & HA & IBA & AMF \\
\hline Plant Height $(\mathrm{cm})$ & $183.7 \mathrm{c}$ & $203.07 \mathrm{a}$ & $199.67 b$ & $196.27 b$ & $161.3 \mathrm{~d}$ & $193.2 \mathrm{a}$ & $185.33 \mathrm{~b}$ & $181.28 \mathrm{c}$ \\
\hline No. of Branches & $5.73 \mathrm{~d}$ & $9.93 \mathrm{a}$ & $8.63 \mathrm{~b}$ & $7.13 \mathrm{c}$ & $7.2 \mathrm{~d}$ & $11.53 \mathrm{a}$ & $10.03 \mathrm{~b}$ & $8.99 \mathrm{c}$ \\
\hline Stem Diameter $(\mathrm{cm})$ & $1.52 \mathrm{~b}$ & $2.099 \mathrm{a}$ & $1.57 \mathrm{~b}$ & $1.74 \mathrm{~b}$ & $1.54 \mathrm{~b}$ & $1.96 \mathrm{a}$ & $1.69 \mathrm{~b}$ & $1.68 \mathrm{~b}$ \\
\hline Leaf Area $\left(\mathrm{cm}^{2}\right)$ & $1.70 \mathrm{~d}$ & $3.34 \mathrm{a}$ & $2.14 \mathrm{c}$ & $2.81 \mathrm{~b}$ & $1.67 \mathrm{~d}$ & $3.35 \mathrm{a}$ & $2.19 \mathrm{c}$ & $2.75 \mathrm{~b}$ \\
\hline Shoot Fresh Weight (g) & $947.67 d$ & $1068.97 \mathrm{a}$ & $999.00 \mathrm{c}$ & $1038.00 \mathrm{~b}$ & $961.93 \mathrm{~d}$ & $1083.70 \mathrm{a}$ & $1002.1 \mathrm{c}$ & $1039.00 \mathrm{~b}$ \\
\hline Shoot Dry Weight (g) & $194.33 \mathrm{~d}$ & $247.19 \mathrm{a}$ & $229.38 b$ & $221.33 \mathrm{c}$ & $200.23 \mathrm{~d}$ & $250.91 \mathrm{a}$ & $230.85 \mathrm{~b}$ & $220.78 \mathrm{c}$ \\
\hline No. of Fruits/Plant & $68.37 \mathrm{~d}$ & $124.87 \mathrm{a}$ & $112.17 \mathrm{c}$ & $118.54 \mathrm{~b}$ & $70.25 \mathrm{~d}$ & $140.67 \mathrm{a}$ & $121.8 \mathrm{c}$ & $131.67 \mathrm{~b}$ \\
\hline $\begin{array}{l}\text { Fruits Fresh Weight /Plant } \\
(\mathrm{g})\end{array}$ & $359.2 \mathrm{~d}$ & $758.44 \mathrm{a}$ & $486.29 c$ & $606.93 \mathrm{~b}$ & $302.4 \mathrm{c}$ & $969 \mathrm{a}$ & $337.1 \mathrm{c}$ & $421.2 \mathrm{~b}$ \\
\hline Dry Sepals Yield / Plant (g) & $25.67 \mathrm{~d}$ & $52.45 \mathrm{a}$ & $43.26 \mathrm{c}$ & $47.68 \mathrm{~b}$ & $25.67 \mathrm{~d}$ & $52.45 \mathrm{a}$ & $43.26 \mathrm{c}$ & $47.68 \mathrm{~b}$ \\
\hline
\end{tabular}

Means having the same letter (s) within the same row are not significantly different according to LSD for all-pairwise comparisons test at 5\% level of probability. *(HA) Humic acid, (IBA) Indole butyric acid, (AMF) Arbuscular mycorrhizal fungi. 
The increase in fruit fresh weight and sepals dry weight might be due to the effects of humic acid treatment in increasing the photosynthetic activity and different metabolic processes. Also, humic acid plays an important role in stimulating and increasing cell division, as well as optimized uptake of nutrients and water (Atiyeh et al., 2002 and Chen et al., 2004), which leads to increase fruit fresh weight then sepals dry weight. The aforementioned results were similar to those of Khalil and Yousef (2014), Al-Mohammad et al. (2016) and Hewidy et al. (2018) on Hibiscus sabdariffa L.

Arbuscular mycorrhizal fungi (AMF), have been shown to promote plant growth by many researchers, such as (a) enhancing nutrient uptake (Evelin et al. 2012); (b) improving rhizospheric and soil conditions (Asghari et al. 2005); (c) producing plant growth hormones and (d) improvement in photosynthetic activity or water use efficiency (Hajiboland et al. 2010). The increment of vegetative growth parameters by using AMF are inagree with those reported by Kasliwal and Srinivasamurthy (2016) on Hibicus rosa sinensis.

The role of IBA in increasing plant growth may be to the fact that IBA produced healthier lengthy roots and vigorous root system which enhanced the absorption of minerals and water from the soil resulting in produce more branches, more number of leaves and increasing leaf area. The increase in leaf area increases the photosynthetic activity resulting in increased carbohydrates which results in high growth (Kaur, 2015). These results were similar to the findings of Shahab et al., (2013) on Alstonia.

\section{Leaf chlorophyll $a$ and $b$ and total carotenoid contents of leaves of $\boldsymbol{H}$. sabdariffa}

Data in Table (2) showed generally that the application of humic acid treatment significantly increased the highest values of leaf chlorophyll a, b and total carotenoid contents compared to the other treatments, in both seasons. However, the differences between humic acid and indole butyric acid in total carotenoid were the same in both seasons. Humic acid treatment recorded the highest values of chlorophyll a (17.72 and $18.03 \mu \mathrm{g} / \mathrm{mL}$ ) and chlorophyll $\mathrm{b}$ (8.47 and $8.19 \mu \mathrm{g} / \mathrm{mL}$ ) in the first and second seasons, respectively. Also, humic acid and indole butyric acid treatments recorded the highest values of total carotenoid contents (3.95 and $4.09 \mu \mathrm{g} / \mathrm{mL})$ and $(4.24$ and $4.39 \mu \mathrm{g} / \mathrm{mL}$ ) for the first and second seasons, respectively.
The enhancement effect of humic acid in increasing photosynthesis pigments might be due to its ability to increase the activity of soil organisms, which in turn release more nutrients such as iron from unavailable reserves that produce more chlorophyll pigments (Wallace and Khadr, 1996). Moreover, Dekock (1955) reported that humic acid prevents the immobilization of $\mathrm{Fe}$ and $\mathrm{P}$ and facilitates their translocation from roots to shoots making them available for plants in chlorophyll production. Tahir et al. (2011) reported that leaf chlorophyll content was associated with humic acid substances as a result of increased cell membrane permeability, thus increasing the absorption of nutrients, especially nitrogen. Current results of humic acid were in harmony with those reported by Koocheki et al. (2016) on Crocus sativus L. and Ariafar and Forouzandeh (2017) on black cumin.

The enhancement effect of indole butyric acid (IBA) in increasing photosynthesis pigments might be due to the stimulatory effect on the amount of metabolites synthesized through enhancement of cell division and chlorophyll accumulation which led to higher rate of photosynthesis (Midan et al. 1982 and Ludwig-Müller et al. 2000). The obtained results of indole butyric acid were in agreement with those obtained by Shaddad and El-Tayeb (1990) and Abdel-Wahed and Amin (2006) on maize.

\section{Phytochemical analyses of Calyces}

Data in Tables (2 and 3) showed the calyx chemical composition of Roselle plants during the two growing seasons of 2015/2016 and 2016/2017. Regarding the effect of individual treatment of HA, IBA and AMF, data in Table 2 showed that there were significant differences between all treatments in increasing calyx chemical composition parameters compared to control, in both seasons. Humic acid was the most effective treatment compared to the rest of treatments in increasing moisture content (13.40 and 13.02\%), ash content (13.45 and $13.69 \mathrm{~g} / 100 \mathrm{~g}$ DW), total acidity (19.59 and $19.53 \%)$, total carbohydrate contents (67.63 and $67.2 \mathrm{~g} / 100 \mathrm{~g} \mathrm{DW})$ and total protein content (11.14 and $11.03 \mathrm{~g} / 100 \mathrm{~g} \mathrm{DW}$ ) for the first and second season, respectively.

The reason behind increasing moisture content as a result of humic acid application might be attributed to the role of humic acid in increasing uptake of both macro and micronutrients availability for plants (Maggioni et al., 1987 and Mackowiak et al., 2001), which lead to exposing water quantities, then increasing moisture availability (Sonnenberg, 2012). The moisture contents might be affected by genetic factors and the long storing period of the Roselle calyces, which cause the dryness (Suliman et al., 2011). 
Table 2. The effect of HA, IBA and mycorrhiza (AMF) on leaves pigments content and calyx chemical composition parameters of Roselle plant during the two seasons of 2015/2016 and 2016/2017

\begin{tabular}{|c|c|c|c|c|c|c|c|c|}
\hline \multirow{2}{*}{ Parameters } & \multicolumn{4}{|c|}{2016} & \multicolumn{4}{|c|}{2017} \\
\hline & Control & HA & IBA & AMF & Control & HA & IBA & AMF \\
\hline \multicolumn{9}{|c|}{ Leaves pigments content } \\
\hline Chlorophyl a $(\mu \mathrm{g} / \mathrm{mL})$ & $12.17 \mathrm{c}$ & $17.72 \mathrm{a}$ & $16.12 \mathrm{~b}$ & $13.94 \mathrm{~b}$ & $12.71 \mathrm{~d}$ & $18.03 \mathrm{a}$ & $16.50 \mathrm{~b}$ & $14.65 \mathrm{c}$ \\
\hline Chlorophyl b $(\mu \mathrm{g} / \mathrm{mL})$ & $6.21 \mathrm{c}$ & $8.47 \mathrm{a}$ & $7.02 \mathrm{~b}$ & $7.34 \mathrm{~b}$ & $6.51 \mathrm{~b}$ & $8.19 \mathrm{a}$ & $7.26 \mathrm{ab}$ & $7.17 \mathrm{ab}$ \\
\hline Total Carotenoids $(\mu \mathrm{g} / \mathrm{mL})$ & $3.71 \mathrm{~b}$ & $3.95 \mathrm{a}$ & $4.42 \mathrm{a}$ & $3.22 \mathrm{c}$ & $3.75 \mathrm{~b}$ & $4.09 \mathrm{a}$ & $4.39 \mathrm{a}$ & $3.43 \mathrm{~b}$ \\
\hline \multicolumn{9}{|c|}{ Calyx chemical composition parameters } \\
\hline Moisture (\%) & $12.94 \mathrm{c}$ & $13.40 \mathrm{a}$ & $12.67 \mathrm{~d}$ & $13.25 \mathrm{~b}$ & $12.47 \mathrm{~b}$ & $13.02 \mathrm{a}$ & $12.39 \mathrm{~b}$ & $12.45 \mathrm{~b}$ \\
\hline Ash (g/ 100g DW) & $11.71 \mathrm{~b}$ & $13.45 \mathrm{a}$ & $10.18 \mathrm{c}$ & $10.21 \mathrm{c}$ & $10.06 \mathrm{~d}$ & $13.69 \mathrm{a}$ & $10.41 \mathrm{c}$ & $11.78 \mathrm{~b}$ \\
\hline Acidity (\% as a citric acid) & $19.18 \mathrm{c}$ & $19.59 \mathrm{a}$ & $19.06 \mathrm{~d}$ & $19.37 \mathrm{~b}$ & $19.14 \mathrm{c}$ & $19.53 \mathrm{a}$ & $18.98 \mathrm{~d}$ & $19.26 \mathrm{~b}$ \\
\hline Total Carbohydrates (g/ 100g DW) & $66.93 \mathrm{~b}$ & $67.63 \mathrm{a}$ & $65.26 \mathrm{c}$ & $66.93 \mathrm{~b}$ & $66.34 \mathrm{c}$ & $67.20 \mathrm{a}$ & $65.12 \mathrm{~d}$ & $66.75 \mathrm{~b}$ \\
\hline Total Protein (g/ 100g DW) & $10.44 \mathrm{c}$ & $11.14 \mathrm{a}$ & $10.37 \mathrm{c}$ & $11.06 \mathrm{~b}$ & $10.56 \mathrm{c}$ & $11.03 \mathrm{a}$ & $10.15 \mathrm{~d}$ & $10.89 \mathrm{~b}$ \\
\hline $\mathrm{pH}$ & $2.73 \mathrm{a}$ & $2.60 \mathrm{c}$ & $2.72 \mathrm{a}$ & $2.65 \mathrm{~b}$ & $2.74 \mathrm{a}$ & $2.61 \mathrm{~b}$ & $2.74 \mathrm{a}$ & $2.63 \mathrm{~b}$ \\
\hline Total Lipids (g/ 100g DW) & $0.80 \mathrm{~b}$ & $0.83 \mathrm{a}$ & $0.85 \mathrm{a}$ & $0.85 \mathrm{a}$ & $0.82 \mathrm{~b}$ & $0.92 \mathrm{a}$ & $0.93 \mathrm{a}$ & $0.89 \mathrm{a}$ \\
\hline Crude Fiber (g/ 100g DW) & $10.12 \mathrm{c}$ & $10.22 \mathrm{~b}$ & $10.08 \mathrm{c}$ & $10.45 \mathrm{a}$ & $10.39 \mathrm{c}$ & $10.89 \mathrm{~b}$ & $10.10 \mathrm{~d}$ & $11.06 \mathrm{a}$ \\
\hline
\end{tabular}

Means having the same letter (s) within the same row are not significantly different according to LSD for all-pairwise comparisons test at 5\% level of probability. *(HA) Humic acid, (IBA) Indole butyric acid, (AMF) Arbuscular mycorrhizal fungi.

Table 3. The effects of HA, IBA and mycorrhiza (AMF) on calyx chemical composition parameters of Roselle plant during two seasons of 2015/2016 and 2016/2017 analyzed using the HPLC

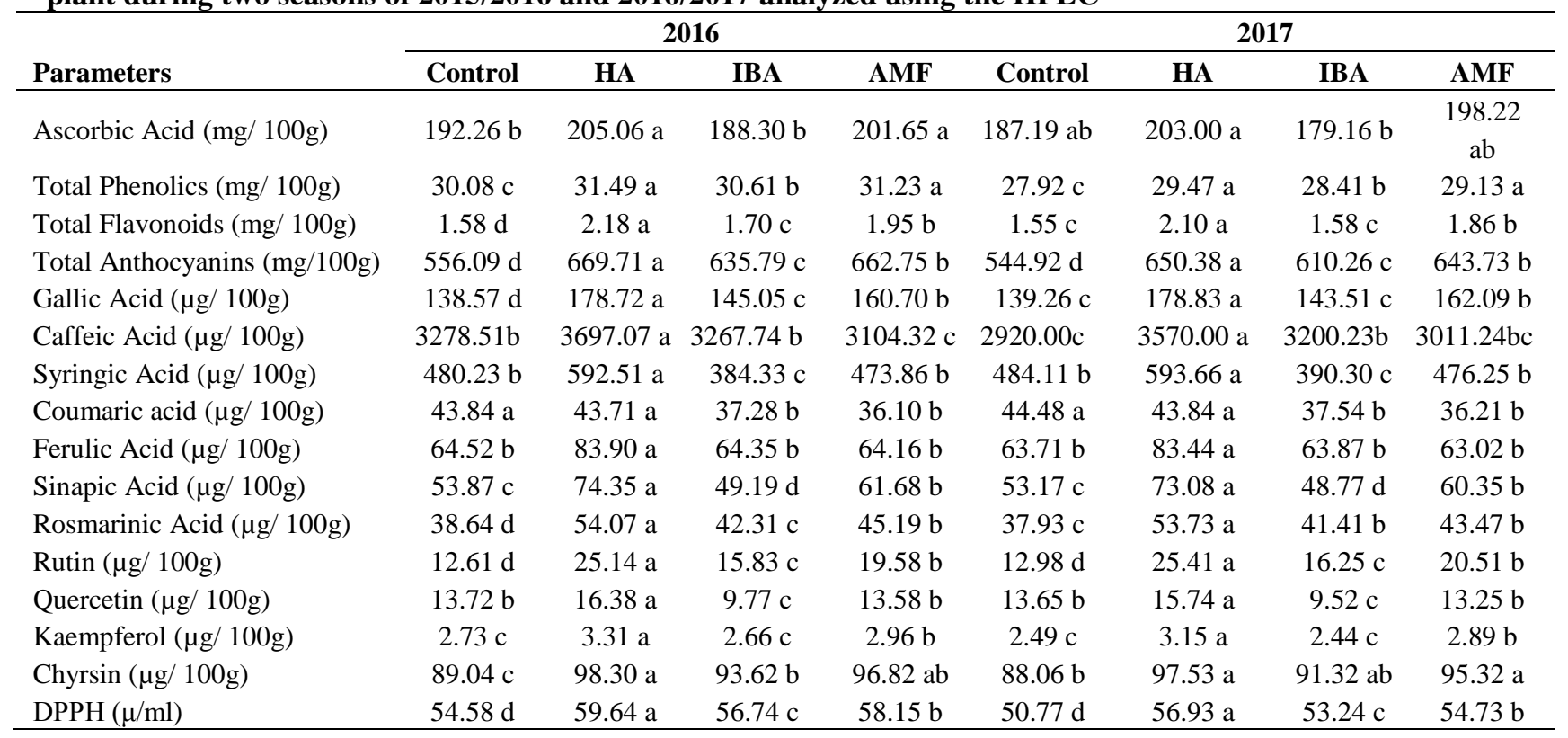

Means having the same letter (s) within the same row are not significantly different according to LSD for all-pairwise comparisons test at 5\% level of probability. *(HA) Humic acid, (IBA) Indole butyric acid, (AMF) Arbuscular mycorrhizal fungi.

The increment of ash content might be attributed to the role of humic acid in increasing root growth, nutrient uptake and consequently stimulated plant growth (Fernandez-Escobar et al., 1999), which leads to increasing calyx dry weight then increasing total solids. Our results of moisture and ash content are in harmony with those of Suliman et al. (2011) on Hibiscus sabdariffa $\mathrm{L}$.

The high acidity of plants treated with humic acid compared to the non-treated plants could be attributed to the utilization of additional carbon source provided from the organic fertilizers in the production of organic 
acids, which are responsible for the fruit acidity (Aminifard et al., 2012). The enhancing effect of humic acid on titratable acidity was in parallel with the findings of Aminifard et al. (2012) on hot pepper and Fallahi et al. (2017) on Roselle.

The increment of total carbohydrate contents with humic acid application might be due to the role of humic acid in increasing root growth by increasing cell elongation or root cell membrane permeability, which lead to increase water and nutrients uptake by increasing root surface area, so increase the process of photosynthesis and the representation of carbohydrates that reflect positively on the process of storage vehicles (AlTohafi et al., 2015). Moreover, the whole Roselle plant is rich in carbohydrates (FAO, 1998). The obtained results were in agreement with Shehata et al. (2011) on strawberry and Gendy et al. (2012) and Fallahi et al. (2017) on Hibiscus sabdariffa L.

The increased total protein by humic acid application might be due to the role of humic acid in the assimilation of major and minor elements, enzyme activation, changes in membrane permeability, protein synthesis and the activation of biomass production (Ulukan, 2008). These results are in harmony with those obtained by Fallahi et al. (2017) on H. sabdariffa L.

It was noticed that the $\mathrm{pH}$ values of sepals ranged from (2.60 to 2.74) in both seasons (Table 2). The highest value of $\mathrm{pH}$ was obtained for control (2.73 and 2.74) and IBA (2.72 and 2.74) treatments in both seasons, respectively. But, the lowest value was obtained after humic acid treatment (2.60 and 2.61). The increment of $\mathrm{pH}$ might be due to the influence of these treatments in producing nitrogenous compounds that increase the $\mathrm{pH}$ value.

Data in Table 2 showed clearly that total lipid contents were less affected by treatments. Although, there were significant differences between all treatments and control in increasing total lipid contents, but there was no significant difference between all treatments of HA, IBA and mycorrhiza (AMF) in increasing total lipid contents. These results were in agreement with that of Ahmed et al. (2019) on H. sabdariffa L. Also, data indicated that the AMF treatment showed the highest value of crude fiber contents. These results were slightly less than the values reported by Suliman et al. (2011) that were ranged between (13.2 and $12 \mathrm{~g} / 100 \mathrm{~g}$ DW).

It was clear from data in Table 3 that there were significant differences between all treatments in increasing calyx chemical composition parameters i.e., ascorbic acid, total phenolics, total flavonoids, total anthocyanin, gallic acid, caffeic acid, syringic acid, coumaric acid, ferulic acid, sinapic acid, rosmarinic acid, rutin, quercetin, kaempferol and chrysin in both seasons compared to the control. The highest value of these parameters was observed after the treatment of humic acid compared to other treatments in both seasons. Also, the treatment with AMF led to a significant increment in total phenolics and chyrsin in both seasons and ascorbic acid content in the first season only. Moreover, control treatment leads to a significant increment in coumaric acid content in both seasons as compared with IBA and AMF treatments.

Current study reported that gallic, caffeic and syringic acids, were the most abundant phenolics in Roselle. Phenolic compounds partially increased by the application of humic acid in both seasons and these results were in line with earlier findings on tomato, where organic nutrition management increased phenolic compounds in fruit (Toor et al., 2006). Humic substances have been shown to enhance the expression of catalyzes enzyme, which was considered the first step in the biosynthesis of phenolic compounds (Canellas et al., 2015). Moreover, Roselle calyces are one of the excellent sources of anthocyanins. These compounds contribute significantly in enhancing health as a good source of antioxidants as well as a natural food colourant (Chumsri et al., 2008). The increase of anthocyanin in fruits after the humic acid treatment might be attributed to the increase in vegetative growth and leaf area (Table1), which has increased the photosynthesis products that involved in pigment production (Dumas et al., 2003). Also, humates increase the uptake of both macro and micronutrients (Maggioni et al., 1987 and Mackowiak et al., 2001), which play an important role in the production of pigments. Moreover, the role of humic acid (phenolic compound derivatives) as a precursor for the synthesis of anthocyanin (flavonoid structure), which increase the antioxidants activity (Ahmed et al., 2011). Shehata et al. (2011) reported that, by using compost, the anthocyanin levels in strawberry fruit have increased. The previous data of calyx anthocyanin content in close conformity with the findings of Gendy et al. (2012), Fallahi et al. (2017), Hashem et al. (2017) and Attiam (2018) on H. sabdariffa $\mathrm{L}$.

Antioxidant activity determined by DPPH method (Brand-Williams et al., 1995) showed increased values of DPPH after the humic acid treatment (Table 3). These results were consistent with the values of ascorbic acid, total phenolic, total flavonoids and total anthocyanin content reported by Al-Kahtani and Hassan (1990) and Sukhapat et al. (2004). The increment of antioxidants content in Roselle sepals by humic acid application might be due to the role of the humic acid in the provision of nutrients and the increase of the efficiency of absorption by the plant and thus increase the process of photosynthesis and carbohydrates (Hendawy, 2008). Ziadi et al. (2001) and Achuo et al. (2004) indicated that the foliar application of humic acid 
consistently increase the antioxidants such as $\alpha$ tocopherol, $\alpha$-carotene, superoxide dismutase, and ascorbic acid concentrations in turf grass species. Finally, these results showed that humic acid was required to provide the soil and the plant with nutrient elements that stimulate all metabolism synthesis processes and then increase the secondary metabolism compounds (Al-Mohammad et al., 2016).

\section{Calyx minerals content}

Data in Table (4) indicated that there were significant differences between all treatments in increasing the content of $\mathrm{Ca}, \mathrm{Mg}, \mathrm{K}, \mathrm{Na}, \mathrm{P}, \mathrm{Fe}$, and $\mathrm{Zn}$ in Roselle plants. Arbuscular mycorrhiza treatment was the most effective treatment compared to the rest of treatments in increasing $\mathrm{Ca}$ content $(936.75$ and 945.50 $\mathrm{mg} / \mathrm{Kg}$ ), P (53.01 and $60.50 \mathrm{mg} / \mathrm{Kg})$, Fe content $(43.68$ and $45.80 \mathrm{mg} / \mathrm{Kg}$ ) and $\mathrm{Zn}$ contents $(11.57$ and 11.40 $\mathrm{mg} / \mathrm{Kg}$ ) in calyx in the first and second season, respectively. Also, humic acid treatment showed significant difference and higher values of $\mathrm{Mg}$ content ( 326.50 and $304.50 \mathrm{mg} / \mathrm{Kg}$ ), $\mathrm{K}$ content ( 37.75 and 36.25 $\mathrm{mg} / \mathrm{Kg}$ ) and $\mathrm{P}$ contents $(63.03$ and $60.90 \mathrm{mg} / \mathrm{Kg}$ ) for the first and second seasons, respectively. Furthermore, Na content was decreased after the applications of HA, IBA and AMF treatments compared to the control in both seasons.

In general, minerals content in plants depends on many factors such as fertilization, and genetic factors. Many studies indicated that negatively charged particles of humates help in chelating most of plant nutrients and water molecules. Humates are beneficial in release nutrients in the soil so that they became available to plants. Also, humates might promote the uptake of some nutrients and reduce the uptake of toxic elements (Khaled and Fawy, 2011). Humates ameliorate nutrient uptake especially phosphorus, stimulates soil biological activity, and acts as a storehouse of $\mathrm{N}$ (Mazhar et al., 2012). Also, the application of humates increased the uptake of both macro and micronutrients availability for plants (Maggioni et al., 1987 and Mackowiak et al., 2001). Humic acid plays a positive effect on cell membrane functions by promoting nutrient uptake, respiration, biosynthesis of nucleic acid, ion absorption, enzyme because it is hormone-like substance (Yang et al., 2004). Mycorrhiza improves the plant growth by capturing relatively immobile nutrients like phosphorus (Souchie et al., 2006), macro-elements (Hodge et al., 2001), and some microelements (Faber et al., 1990 and Anju et al., 2011). Mycorrhizal hyphae simplify the absorption of available forms of nutrients by increasing the effective soil volume and adjustment of soil chemical properties (Sembok et al., 2015). Therefore, uptake of nutrients such as $\mathrm{P}, \mathrm{N}, \mathrm{K}, \mathrm{Fe}, \mathrm{Zn}, \mathrm{Cu}, \mathrm{Mg}, \mathrm{S}$, and other ions, is usually improved by mycorrhiza inoculation (Aulia et al., 2009). Earlier studies have also shown that AMF (Glomus mosseae) increases the $\mathrm{P}$ content, $\mathrm{Zn}$ concentration, bio volume index and quality index (Sumana and Bagyaraj, 1999). The aforementioned results are in good accordance with those postulated by Gendy et al. (2012) on H. sabdariffa $\mathrm{L}$ and Kasliwal and Srinivasamurthy (2016) on H. rosa sinensis.

Table 4. The effects of HA, IBA and mycorrhiza (AMF) on calyx mineral contents of Roselle plant during the two seasons of 2015/2016 and 2016/2017

\begin{tabular}{lcccccccc}
\hline \multirow{2}{*}{ Mineral } & \multicolumn{9}{c}{ 2016 } & \multicolumn{4}{c}{$\mathbf{2 0 1 7}$} \\
\cline { 2 - 8 } & Control & HA & IBA & AMF & Control & HA & IBA & AMF \\
\hline $\mathrm{Ca}(\mathrm{mg} / \mathrm{Kg})$ & $872.25 \mathrm{~d}$ & $919.75 \mathrm{~b}$ & $880.00 \mathrm{c}$ & $936.75 \mathrm{a}$ & $847.50 \mathrm{c}$ & $881.00 \mathrm{~b}$ & $841.50 \mathrm{~d}$ & $945.50 \mathrm{a}$ \\
$\mathrm{Mg}(\mathrm{mg} / \mathrm{Kg})$ & $293.00 \mathrm{~d}$ & $326.50 \mathrm{a}$ & $301.25 \mathrm{c}$ & $311.25 \mathrm{~b}$ & $284.00 \mathrm{~d}$ & $304.50 \mathrm{a}$ & $288.00 \mathrm{c}$ & $295.50 \mathrm{~b}$ \\
$\mathrm{~K}(\mathrm{mg} / \mathrm{Kg})$ & $35.00 \mathrm{c}$ & $37.75 \mathrm{a}$ & $32.66 \mathrm{~d}$ & $36.08 \mathrm{~b}$ & $34.50 \mathrm{c}$ & $36.25 \mathrm{a}$ & $32.13 \mathrm{~d}$ & $34.97 \mathrm{~b}$ \\
$\mathrm{Na}(\mathrm{mg} / \mathrm{Kg})$ & $13.38 \mathrm{a}$ & $12.43 \mathrm{~b}$ & $12.63 \mathrm{~b}$ & $12.62 \mathrm{~b}$ & $13.80 \mathrm{a}$ & $12.35 \mathrm{~b}$ & $12.10 \mathrm{~b}$ & $12.90 \mathrm{~b}$ \\
$\mathrm{P}(\mathrm{mg} / \mathrm{Kg})$ & $61.43 \mathrm{~b}$ & $63.03 \mathrm{a}$ & $60.15 \mathrm{c}$ & $63.01 \mathrm{a}$ & $59.50 \mathrm{~b}$ & $60.90 \mathrm{a}$ & $58.05 \mathrm{c}$ & $60.50 \mathrm{a}$ \\
$\mathrm{Fe}(\mathrm{mg} / \mathrm{Kg})$ & $38.33 \mathrm{~d}$ & $41.68 \mathrm{~b}$ & $39.82 \mathrm{c}$ & $43.68 \mathrm{a}$ & $39.85 \mathrm{~d}$ & $44.20 \mathrm{~b}$ & $41.09 \mathrm{c}$ & $45.80 \mathrm{a}$ \\
$\mathrm{Zn}(\mathrm{mg} / \mathrm{Kg})$ & $8.84 \mathrm{~d}$ & $10.13 \mathrm{c}$ & $10.70 \mathrm{~b}$ & $11.57 \mathrm{a}$ & $8.58 \mathrm{~d}$ & $9.75 \mathrm{c}$ & $10.20 \mathrm{~b}$ & $11.40 \mathrm{a}$ \\
\hline
\end{tabular}

Means having the same letter (s) within the same column are not significantly different according to LSD for all-pairwise comparisons test at 5\% level of probability *(HA) Humic acid, (IBA) Indole butyric acid, (AMF) Arbuscular mycorrhizal fungi. 


\section{CONCLUSION}

Results of the current study indicated, generally, that application treatments of humic acid, indole butyric acid, and AMF to Roselle plants gave the highest yield and good quality compared to un treated plants. Humic acid might be considered as an optimal treatment for the production of high yield and good quality of Roselle plants under the envirinmenal conditions of EL-Beheira Governorate and other similar regions.

\section{REFERENCES}

Abdel-Wahed, M.S.A. and A.A. Amin. 2006. Physiological effect of some bioregulators on vegetative growth, yield and chemical constituents of yellow maize plants. World J. of Agric. Sci. 2(2): 149-155.

Abu-Tarboush, H. M. and S. A. B. Ahmed. 1996. "Studies on Karkade (Hibiscus sabdariffa L.): Protease Inhibitors, Phytate, in Vitro Digestibility and Gossypol Content." Food Chem. 56: 15-9.

Achuo, E. A., K. Audenaert, H. Meziana and M. Hofte. 2004. The salicylic acid dependent defense pathway is effective against different fungi in tomato and tobacco. Plant Pathol. 53(1): 65-72.

Ahmadian, A., A. Tavassoli and E. Amiri. 2011. The interaction effect of water stress and manure on yield components, essential oil and chemical compositions of cumin (Cuminum cyminum). Afr. J. Agric Res. 6(10): 2309-2315.

Ahmed, F. A. M., N. M. E. Satti and S. E. H. Eltahir. 2019. A comparative study on some major constituents of Karkade (hibiscus sabdariffa 1. - Roselle plant). Int. J. Life Sci. Pharma Res. 9 (1): (L) 1-12.

Ahmed, M.Y., E. A. Shalaby and N. T. Shanan. 2011. The use of organic and inorganic cultures in improving vegetative growth, yield characters and antioxidant activity of Roselle plants (Hibiscus sabdariffa L.). African J. of Biotechnology. 10(11): 1988-1996.

Al-Kahtani, H. and B.H. Hassan. 1990. Spray drying of Roselle (Hibiscus sabdariffa L.) extract. J. Food Sci. 55(4): 1073-1076.

Al-Mohammad, M. H. S., S. A. Ihsan and H. G. K. AlMousawi. 2016. The Impact of Spraying Humic Acid and Gibberellic Acid on Growth, Yield and Chemical Constituents of Roselle Calyces Hibiscus sabdariffa L. 16th Annual International Conference on the Sci. of Botanicals (ICSB) \& 5th Interim American Society of Pharmacognosy (ASP). 5 (85): 32.

Al-Rawy, K.M. and A.M. Khalaf-allah. 1980 Design and analysis of Agricultural experiments. Textbook El-Mousl Univ. Iraq. 19: 487.

AlTohafi, S. A. A, A. S. Hussain, H. A. Habeeb and N. H. Azab. 2015. The response of growth and yield of Rosella for adding clean salt and spraying with organic fertilizer in high salinity soil. Al- Kufa J.of Agricultural Sci. 7 (1): 73 93. In Arabic.
Aminifard, M. H., A. H. A. M. H. Nemati and H. Z. E. Jaafar. 2012. Effect of humic acid on antioxidant activities and fruit quality of hot pepper (Capsicum annuum L.). J. of Herbs, Spices and Medicinal Plants. 18(4):360-69.

Anju, T., A. Aggarwal, A. Yadav and N. Kadian. 2011. Enhanced growth and yield of Capsicum annum L.with two endomycorrhizal fungi and other bioinoculants. J. of Indian Botanical Sci. 90 (3 - 4): 351-359.

Anokwuru, C. P., I.Esiaba, O. Ajibay and A. O. Adesuyi. 2011. "Polyphenolic Content and Antioxidant Activity of Hibiscus sabdariffa Calyx." Research J. of Medicinal Plants. 5: 557-66.

AOAC. 2000. Association of official analytical chemists. (17th Ed.). Official method of analysis Washington D.C., USA.

Ariafar, S. and M. Forouzandeh. 2017. Evaluation of humic acid application on biochemical composition and yield of black cumin under limited irrigation condition. Increased Chemical characters. Bull Soc R Sci. de Liège. 86:13-24.

Asghari, H.R., P. Marschner, S. E. Smith and F. A. Smith. 2005. Growth response of Atriplex nummularia to inoculation with arbuscular mycorrhizal fungi at different salinity levels. Plant Soil. 373:245-256.

Atiyeh, R. M., C. A. Edward, S. Subler and J. D. Metzger. 2000. Earthworm processed organic wastes as components of horticultural potting media for growing marigold and vegetable seedlings. Compost Sci. Util. 8(3): 215-223.

Atiyeh, R. M., S.Lee, C. A.Edwards, N. Q. Arancon, and J. D. Metzger. 2002. The influence of humic acids derived from earthworm processed organic wastes on plant growth. Bioresour. Technol. 84(1): 7-14.

Attia, E. M. and R. M. Khater. 2015. Effect of different planting dates and organic fertilizers treatments on growth and yield of Hibiscus sabdariffa L. plants. Egyptian J. Desert Res., 65(1):153-170.

Attiam, M. F. 2018. Effect of Organic and Inorganic Fertilization with Spraying of Fulvic Acid on Nutrients Uptake, Quality and Yield of Roselle (Hibiscus sabdariffa L.) Plant Grown in Sandy Soil at Siwa Oasis, Egypt. Alexandria science exchange j. 39 (4):783 - 799.

Aulia, R.A., O. Mohamad, M. Marlina, H. Rasli, S.N. Fuad and A.I. Zainal. 2009. Effects of mycorrhiza on productivity of Roselle. In Congr. of the 8th Malaysia Congress on Genetics. August (4-6).

Black, C.A., D. D. Evans and R.C. Dinauer. 1965. Methods of soil analysis. Madison, WI: Amer. Soc. of Agron. 9: 653708.

Brand-Williams, W., M. E. Cuvelier and C. Benset. 1995. Use of free radical method to evaluate antioxidant activity. Lebensm. Wiss. Technol. 28(1): 25-30.

Canellas, L.P., F.L. Olivares, N.O. Aguiar, D.L. Jones, A. Nebbioso, P. Mazzei and A. Piccolo. 2015. Humic and fulvic acids as biostimulants in horticulture. Scientia Horticulturae. 196:15-27.

Chen, Y. and T.Aviad. 1990. Effects of humic substances on plant growth 1. Humic substances in soil and crop sciences: Selected readings. (humicsubstances). 161-186. 
Chen, Y., M. De Nobili and T.Aviad. 2004. Stimulatory effects of humic substances on plant growth. Soil organic matter in sustainable agriculture. 103-129.

Christie, W. W. 1983. Lipids. In: Aliphatic and related natural product chemistry. (2nd Ed) Pergamon Press Oxford.

Chumsri, P., A. Sirichote and A. Itharat. 2008. Studies on the optimum conditions for the extraction and concentration of Roselle (Hibiscus sabdariffa Linn.) extract. Songklanakarin J. Sci. Technol. 30 (1): 133-139.

Cline, M. G. 2000. Execution of the auxin replacement apical dominance experiment in temperate woody species. American J. of Botany. 87(2): 182-190.

Dasgan, H.Y., S. Kusvuran and I.Ortas. 2008. Responses of soilless grown tomato plants to arbuscular mycorrhizal fungal (Glomus fasciculatum) colonization in re-cycling and open systems. Afr. J. Biotechnol. 7(20):3606-3613.

Dekock, P. C. 1955. Influence of humic acids in plant growth. Sci. 121(3144): 473-474.

Du, C. T. and F. J. Francis. 1973. Anthocyanins of Roselle (Hibiscus sabdariffa L.) J. Food Sci. 38(5): 810-812.

Duke, I. A. 1979. "Eco-systematic Data on Economic Plants." Quart J. Crude Drug Res. 17 (3-4): 91-110.

Dumas, Y., M. Dadomo, G. D. Lucca and P.Grolier. 2003. "Effect of Environmental Factors and Agricultural Techniques on Antioxidant Content of Tomatoes." J. of the Sci. of Food and Agriculture. 83(5): 369-82.

Eghbal, B., D. Ginting and J. E.Gilley. 2004. Residual effects of manure and compost applications on corn production and soil properties. Agron J. 96(2): 442-447.

Evelin, H., B. Giri and R. Kapoor. 2012. Contribution of Glomusintraradices inoculation to nutrient acquisition and mitigat ion of ionic imbalance in $\mathrm{NaCl}$-stressed Trigonellafoenum-graecum. Mycorrhiza. 22:203-217.

Faber, B. A., R. J. Zasoki, R. G. Burau and K. Uriu. 1990. Zinc uptake by corns as affected by Vesicular Arbuscular mycorrhiza. Plant and soil. 129(2):121-130.

Fallahi, H. R., M.Ghorbany, M. Aghhavani-Shajari, A. Samadzadeh and A.H. Asadian 2017. Qualitative response of Roselle to planting methods, humic acid application, mycorrhizal inoculation and irrigation management. J. of crop improvement. 31(2):192-208.

FAO. 1998. Carbohydrates in human nutrition. Report of a Joint FAO/WHO Expert Consultation. FAO Food and Nutrition Paper No. 66. Rome; Available from: https://www.ncbi.nlm.nih.gov/pubmed/9743703.

Fernandez-Escobar, R., M.Benlloch, D.Barranco, A.Duenas and J. A. Gutérrez Ganan. 1999. Response of olive trees to foliar application of humic substances extracted from leonardite. Sci. Hortic. 66(3-4):191-200.

Gendy, A. S. H., A.Said, H. A. H. Ahl and A. A. Mahmoud. 2012. Growth, Productivity and Chemical Constituents of Roselle (Hibiscus sabdariffa L.) Plants as Influenced by Cattle Manure and Biofertilizers Treatments. Australian J. of Basic and Applied Sci. 6(5): 1-12.
Hajiboland, R., N.Aliasgharzadeh, S. F. Laiegh and C. Poschenreider. 2010. Colonization with arbuscular mycorrhizal fungi improves salinity tolerance of tomato (Solanum lycopersicum L.) plants. Plant Soil. 331:313327.

Hartmann, H. T., D. E. Kester and F. T. Davies. 1990. Plant Propagation: Principles and Practices. Englewood Cliffs, NJ: Prentice-Hall. 246-247.

Hashem, H. A. E. A., A. E. A. EL-Hadidy and E. A. Ali. 2017. Impact of some safe agricultural treatments on insect pests, vascular wilt disease management and Roselle (Hibiscus sabdariffa L.) productivity under Siwa Oasis conditions. Int. J. Environ. 6 (4): 139-162.

Hassan, F. 2009. "Response of Hibiscus sabdariffa L. Plant to Some Biofertilization Treatments". Annals Agric. Sci. 54 (2): 437-46.

Hendawy, S. F. 2008. Comparative study of organic and mineral fertilization on (Plantago arenaria) plant. J. of Applied Sci. Res. 4(5): 500-506.

Hewidy, M., E. Sultan and M. Elsayed. 2018. Water Schedule of Roselle (Hibiscus sabdariffa L.) Under Organic Fertilization. Egypt. J. Hort. Vol. 45(1): 53 - 64.

Hodge, A., C. D. Campbell and A. H. Fitter. 2001. An Arbuscular mycorrhizal fungus accelerates decomposition and acquires nitrogen directly from organic material.Nature.413(6853):297-299.

Hwang, E. S. and N. Do-Thi. 2014. Effects of extraction and processing methods on antioxidant compound contents and radical scavenging activities of laver (Porphyra tenera). Prev Nutr Food Sci. 19(1):40-48.

Ismail, A., E. H. K. Ikram and H. S. M. Nazri. 2008. Roselle (Hibiscus sabdariffa L.) seeds nutritional composition protein quality and health benefits. Food. 2(1):1-16.

Jain, V. K. 2002. Fundamentals of Plant Physiology, 5th ed., New Delhi, India: S. Chand and Co. Ltd. 444.

Kalvanagh, J. S. and A. N. Heris. 2013. The Effect of water deficit stress, organic and inorganic fertilizers on yield and yield components of dragon's head (Lallemantia iberica). International J. of Agronomy and Plant Production. 4 (7): 1558-1563.

Kasliwal, S. and K. M. Srinivasamurthy. 2016. Influence of Arbuscular Mycorrhizae Inoculation on Growth and Development of Hibiscus rosa sinensis. Int. J. Curr. Microbiol. App. Sci. 5(3): 659-666.

Kaur, S. 2015. Effect of different treatments of Indole-3butyric acid (IBA) on the rooting and growth performance of hardwood cuttings of peach (Prunus persica L. Batch). Agricultural Sci. Digest-A Research J. 35(1):41-45.

Khaled, H. and H. A. Fawy. 2011. Effect of different levels of humic acids on the nutrient content, plant growth, and soil properties under conditions of salinity. Soil \& Water Res. 6 (1): 21-29.

Khalil, A. M., S. E. Khalil and T. B. Ali. 2012. Effect of water stress, antioxidants and humic acid on Capsicum annuum, L. growth, yield and active ingredient under sandy soil conditions. Egypt. J. of Appl. Sci. 27 (1):35-56. 
Khalil, S. E. and A. S. Abdel-Kader. 2011. The Influence of Soil Moisture Stress on Growth, Water Relation and Fruit Quality of Hibisicus sabdariffa L. Grown within Different Soil Types. Natu. Sci. 9(4): 62-74.

Khalil, S. E. and R. M. M. Yousef. 2014. Study the effect of irrigation water regime and fertilizers on growth, yield and some fruit quality of Hibiscus sabdariffa L. International J. of Advanced Research. 2(5): 738-750.

Kim, K. H., R.Tsao, R. Yang and S. W. Cui. 2006. Phenolic acid profiles and antioxidant activities of wheat bran extracts and the effect of hydrolysis conditions. Food Chemistry. 95(3): 466-473.

Kjeldahl, J. 1983. Determination of protein nitrogen in food products. Encyc. Food Agric. 28: 757-765.

Koocheki, A., H. R.Fallahi, M. B. Amiri and H. R. Ehyaei. 2016. Effects of Humic acid Application and Mother Corm Weight on Yield and Growth of Saffron (Crocus sativus L.). J. Agroecol. 7(4): 1-18.

Lazim, Z. S., S. N. Jasim, Z. M. Ahmad, Q. Abdul Karim and Z. M. Aziz. 2014. Effect of Organicand Chemical Fertilization on the Growth and Yield of Roselle Plants Hibiscus sabdariffa L. J.Agri Sci. and Techno. 4 :779-786.

Lichtenthaler, H. K. and C. Buschmann. 2001. chlorophylls and carotenoids: measurement and characterization by UV-VIS spectroscopy," in Current Protocols in Food Analytical Chemistry, JohnWiley and Sons, New York, NY, USA. 1(1): F 4-3.

Lobartini, J. C., G. A. Orioli and K. H. Tan. 1997. Characteristics of soil humic acid fractions separated by ultrafiltration. Commun. Soil Sci. Plant. 28(9-10): 787796.

Looney, N.E. and D.L.McIntosh. 1968. Stimulation of pear rooting by preplant treatment of nursery stock with indole3-butyric acid. J. Amer. Soc. Hort. Sci. 92:150-154.

Ludwig-Müller, J., B. Schubert and K.Pieper. 1995. Regulation of IBA synthetase by drought stress and abscisic acid. J. Exp. Bot. 46: 423-432.

Ludwig-Müller, J., B. Schubert, W. Rademacher and W. Hilgenberg. 2000. Indole-3-butyric acid biosynthesis in maize is enhanced by cyclohexanedione herbicides. Physiologia Plantarum. 110(4):544-550.

Mackowiak, C. L., P. R. Grossl and B. G. Bugbee. 2001. Beneficial effects of humic acid on micronutrient availability to wheat. Soil Sci. Soc of Amer J. 56(6): 1744-1750.

Maggioni, A., Z.Varanini, S. Nardi and R.Pinton. 1987. Action of soil humic matter on plant roots: Stimulation of ion uptake and effects on $\left(\mathrm{Mg}^{2+}, \mathrm{K}^{+}\right)$ATPase activity. Sci. of the Total Environ. 62:355-363.

Mahadevan, S. and P. Kamboj. 2009. "Hibiscus sabdariffa L.: An Overview.” Nat. Prod. Radiance. 8:77-83.

Mazhar, A. A. M., S. I. Shedeed, N. G. Abdel-Aziz and M. H. Mahgoub. 2012. Growth, flowering and chemical constituents of Chrysanthemum indicum L. plant in response to different levels of humic acid and salinity. J. of Applied Sci. Research. 8(7): 3697-3706.
Midan, A.A., A.M. El-Bakry and N.M. Malush. 1982. Growth, chemical constituents and yield of onion in relation to growth regulators application. Res Bull Fac Agric Zagazig Univ. Egypt (508).

Mukhtar, M. A. 2007. The effect of feeding rosella (Hibiscus sabdariffa) seed on broiler chicks performance. Research J. of Animal and Veterinary Sci. 2(13): 21-23.

Muler, H. G. and G. Tobin. 1980. Nutrition of food processing. Croom Helm Ltd, London. UK.

Mwangi, M.W., E. O. Monda, S. A.Okoth, J. M. Jefwa. 2011. Inoculation of tomato seedlings with Trichoderma harzianum and arbuscular mycorrhizal fungi and their effect on growth and control of wilt in tomato seedlings. Brazilian J. Microbiol. 42(2):508-513.

Pearson, D. 1976. The Chemical Analysis of Food. 7 th ed. Churchill Livingstone, Edinburg London and New York p. 75.

Piccolo, A., S.Nardi, G.Concheri. 1992. Structural characteristics of humic substances as regulated to nitrate uptake and growth regulation in plant systems. Soil Biochem. 24(4): 373-380.

Rauthan, B. S. and M. Schnitzer. 1981. Effects of soil fulvic acid on the growth and nutrient content of cucumber (Cucumis sativus) plants. Plant Soil. 63(3):491-495.

Said-AL Ahl, H. A. H., A. G. EL gendy and E. A. Omer. 2016. Humic acid and Indole acetic acid affect yield and essential oil of Dill grown under two different locations in Egypt. Int J. Pharm Pharm Sci. 8(8):146-157.

Salvioli, A., I.Zouari, M.Chalot, and P. Bonfante. 2012. The arbuscular mycorrhizal status has an impact on the transcriptome profile and amino acid composition of tomato fruit. BMC Plant Biol. 12: 1-12.

SAS. 2013. Version 9.2 of the SAS system for windows. SAS Institute Inc., Cary. NC. USA.

Sembok, W. W., N. Abu-Kassim, Y. Hamzah and Z. A.Rahman. 2015. Effect of Mycorrhizal Inoculation on Growth and Quality of Roselle (Hibiscus sabdariffa L.) Grown in Soiless Culture System. Malaysian Appl. Biol. 44(1): 57-62.

Shaddad, M.A. and M.A. El-Tayeb. 1990. Interactive effects of drought and phytohormones on growth and photosynthetic pigments in some crop plants. Acta Agronomica. 39: 1-18.

Shahab, M., G.Ayub, A.Rahman, A.Rashid, A. Jamal and J.Ali. 2013. Assessment of IBA (Indole Butyric Acid) levels and planting time for rooting and growth of Alstonia Cuttings. J. of Natural Sci. Research. 14(3) :5967.

Shehata, S. A., A. A.Gharib, M.Mohamed, K.F. E. Abdel Gawad and E. A. S.Halaby. 2011. Influence of compost, amino and humic acids on the growth, and yield and chemical parameters of strawberries. J. Medicinal Plants Res. 5(11): 2304-2308.

Singlton, V. L., K. Orthofer and R. M. Lamuela- Raventos. 1999. Analysis of total phenols and other oxidation substitutes and antioxidants by means Folin-Ciocalteu reagent. Methods in Enzymology. 28: 152-176 
Smith, S. E. and D. J. Read. 2008. Mycorrhizal symbiosis, 3rd edition. Academic Press, London. 117-144.

Snedecor, G.W and W.G. Corchan. 1967. Statistical Methods. 6th Edition. Iowa State Univ. Press, Ames, Iowa. U.S.A.

Sonar, B. A., V. R. Kamble and P. D. Chavan. 2013. Native AM Fungal Colonization in Three Hibiscus Species Under $\mathrm{NaCl}$ Induced Salinity. J. Pharm. Biol. Sci. 5(6): 7-13.

Sonnenberg, D.M. 2012. The effects of various drip fertigated water quantities on hydroponically cultivated Cucumis sativa L. Thesis submitted in fulfillment of the requirements for the degree Master of Technology, Horticulture. Cape Peninsula University of Technology, Cape Town.

Souchie, E. L., R. Azcon, J. M. Barea, O. J. Saggin-Junior and E. M. Riberio da Silva. 2006. Phosphate solubilizing and arbuscular mycorrhizal fungi.Pesq Agropec Bras.41(9):1405-1411.

Sukhapat, N., S. Ungphaiboon, A. Itharat, J. Puripattanavong and S. Pinsuwan. 2004. Influence of $\mathrm{pH}$ on antioxidant activity of Roselle (Hibiscus sabdariffa L.) extract in aqueous solution. The 10th World Congress on Clinical Nutrition: Nutrition in the Next Decade: Nutraceutical/Functional Food: Product Performance in Health, Disease and Safety. Abstract book. Organized by PSU, INC and BIOTEC. 30:184.

Suliman, A. M. A., A. O. Ali, S. A. A. Idris and M. A. Y. Abdualrahm. 2011. A Comparative Study on Red and White Karkade (Hibiscus sabdariffa L.) Calyces, Extracts and Their Products. Pakistan J. of Nutrition. 10 (7):680683.

Sumana, D. A. and D. J. Bagyaraj. 1999. Selection of efficient VA-mycorrhizal fungi for inoculating Neem. In: Proceedings of the National conference of Mychorrhiza. Singh S (ed) Barkatulla University, Bhopal. pp 10.

Tahir, M. M., M. Khurshid, M. Z. Khan, M. K. Abbasi and M. H. Kazmi. 2011. Lignite-derived humic acid effect on growth of wheat plants in different soils. Pedosphere. 21(1): 124-131.

Thygesen, A., F.W. Poulsen, B. Min, I. Angelidaki and A.B. Thomsen. 2009. The effect of different substrates and humic acid on power generation in microbial fuel cell operation. Bioresource technology. 100(3):1186-1191.
Toor, R. K., P. S. Geoffrey and H. Anuschka. 2006. Influence of different types of fertilisers on the major antioxidant components of tomatoes. J. of Food Composition and Analysis. 19(1):20-27.

Tüfenkçi, Ş., S. Demir, S. Şensoy, H. Ünsal, E. Demirer, Ç. Erdinç, Ş. Biçer and A. Ekincialp. 2012.The effects of arbuscular mycorrhizal fungi on the seedling growth of four hybrid cucumber (Cucumis sativus L.) cultivars. Turk. J. Agric. For., 36(3): 317-327.

Ulukan, H. 2008. Effect of soil applied humic acid at different sowing times on some yield components in wheat (Triticum spp.) hybrids Int. J. Bot. 4(2): 164-175.

Vaughan, D. 1974. A possible mechanism for Humic Acid action on cell elongation in root segments of Pisum sativum under aseptic conditions. Soil Biology Biochemistry. 6(4):241-247.

Wallace, A. and A. H. Khadr. 1996. Some plant physiological effect of humic acid derived from C.F. leonardit, A. Wallace. 1974., puplication and reports. Laboratory of Nuder Medicine and Radiation Biology of California. mutanten von Chlorella. Planta. 65: 186-194.

Xu, Z., M. Huang, O. Gu, Y. Wang, Y. Cao, X. Du, D. Xu, Q. Huang and F. Li. 2005. Competitive sorption behavior of copper (II) and herbicide propisochlor on humic acids. J. Colloid. Interf. Sci. 287(2): 422-427.

Yang, C. M., M. H. Wang, Y. F. Lu, I. F. Chang and C. H. Chou. 2004. Humic substances affect the activity of chlorophyllase. J. Chem. Ecol. 30:1057-65.

Ziadi, S., S. Barbedette, G. F. Godard, C.Monoti, L. F. D.Corre, D.Silue and D.Lecorre. 2001. Production of pathogenesis related protein in the cauliflower (Brassica oleacea var. botrytis) downy mildew (Peronospora parasistica) pathosystem treated with acidbenzolar-5methyl. Plant Pathol. 50(5): 579-586.

Zidan, E. 1962. Evaluation of some Tomato lines in regard to leaf area efficiency and relation of partial defoliation to early and total yield fruit size, soluble solids, leaf rolling and blossom and rot. Ph. D. Thesis, Cornell Univ. Ithaca. New York. U.S.A.

Zilic, S., A.Serpen, G.Akıllıoglu, M.Jankovic and V.Gökmen. 2012. Distributions of phenolic compounds yellow pigments and oxidative enzymes in wheat grains and their relation to antioxidant capacity of bran and debranned flour. J. of Cereal Sci. 56(3): 652-658. 


$$
\text { الملخص العربي }
$$

تأثير حامض الهيوميك و حمض الإندول بيوتيريك و فطر الميكروهيزا كمفقّزات للنمو على المحصول

\section{والخصائص الكيميائية لنبات الكركديه}

رامي الكناني ، يسري سلامه ، محمود روزن ، هاله بيومي و و عاطف نصابه لخدريه

أجريت تجربتان حقليتان علي مدي موسمين متعاقبين وحمض الإندول بيوتيريك وفطر الميكروهيزا بشكل منفرد قد

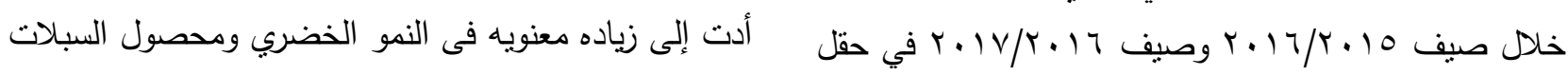

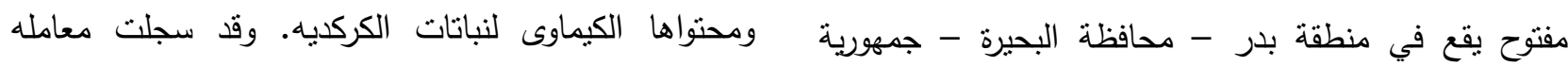

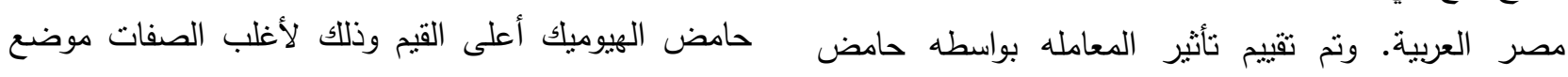

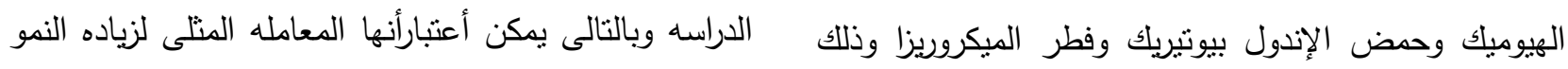

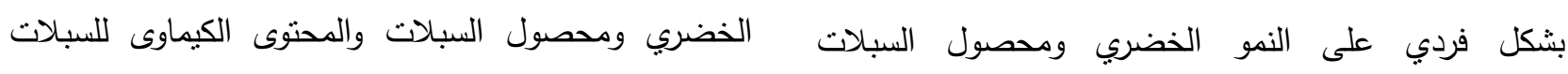

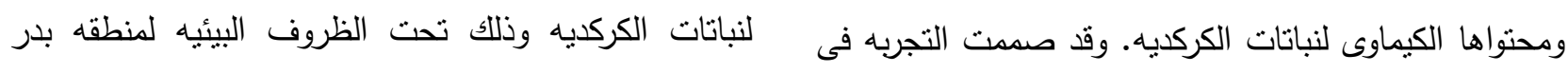

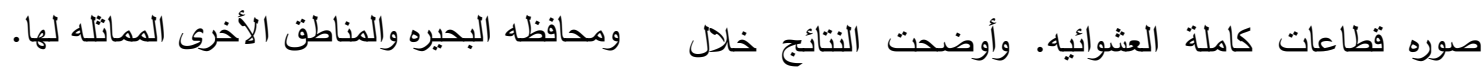
الموسمان بشكل عام أن جميع المعاملات: حامض الهُ الهيوميك 